\title{
Linking Home, School and Community Literacy Events
}

Margaret Early

Lee Gunderson

This article examines the social and cultural value of literacy within home communities. It then considers ways of linking classroom instruction to ways of "doing literacy" in the home/community first by viewing the classroom and school as communities and second by designing classroom instructional practices that reach out to the broader community.

Such practices can not only provide a way to link the organization of instruction to the social world of the child but a way to promote respect among children, and between home and school community members.

\section{INTRODUCTION}

Literacy instruction is the primary goal of teachers. However, there has been debate concerning whether or not school literacy instruction is appropriate or satisfactory (Stein, 1986). Edelsky (1991) suggests that schools do not provide experiences in "authentic literacy" and recommends that traditional school assignments be substituted with real, meaningful, personal reading and writing activities. She also argues that if the literacy activity is simply an exercise it is not authentic. Many teachers across North America have begun to switch from traditional to what they consider to be more authentic instructional activities. The following examples of student writing are part of data collected in an elementary ESL classroom in Vancouver, British Columbia:

\section{ESL Students' Authentic Writing}

1. Do not tuch

(Do not touch)

(Notice to classmates)

2. Classrum Graj Sall

Classroom Garage Sale

(Sign on the door)

3. We are lurning abot the colour of eyes. We made a chart abot eye color. Peple put the color of their grndparnts eyes, their parnts and their color. We made two grops. Light-blue, grey and green, brown, black hazel-dark. Nerly evryone is dark.

(Science log)

4. Arodinamik nose cone and ladder (Kevin) 
Astronuts body (Jason)

(Everybody)

launch pad (Michael)

(Work plan to make spacecraft)

5. Cindy and Kazumi are spi in on us (Note to friend)

6. I don't want come here my mother tell us just the day we leave that day before one. Some say tell me one Not the friend This make me sad I want say good bye I want see again (Note to teacher)

7. March 17 My birthday Please bring the trets We made party Kenji (Classroom poster)

\section{Writing With a Purpose}

Although these samples give some indication of the value of literacy for a group of ESL students in a particular school context, they are not traditional writing assignments given by teachers. Clearly, in this classroom the students wrote for a range of social, personal and academic purposes, arguably authentic literacy. This teacher and her students did not think of writing as a set of discrete skills to be mastered or of the process of writing as a standardized sequence of steps (brainstorming, pre-writing, writing, re-writing). Rather, they thought of writing and reading as activities undertaken in social settings, specifically the school setting, to achieve certain tasks. In her work to develop this concept of literacy and to promote growth in her students' literacy, this teacher gave the students an opportunity to show what they already knew about written language processes and functions from their life experiences. She then built on the considerable linguistic, social and cultural resources which the children brought to the classroom from their home/community. In this way, teacher and students together built an enabling literacy environment.

This article examines the social and cultural value of literacy within home communities and considers ways of linking classroom instruction to ways of "doing literacy" in the home/community.

\section{THE USES OF LITERACY}

Everyday uses of literacy are varied; they are involved in many fundamental areas of life, including living activities such as shopping, paying bills, transportation, filling in forms, entertainment, reading books, magazines, finding out about films, concerts or T.V. schedules, getting general information, doing homework and the like. Yet, despite the range and importance of these activities, there is a tendency in elementary schools across North America for educators to concentrate their attention on only a few of the community literacy activities in which children engage. Myers (1992) rightfully notes that 
"Successful movement towards authentic literacy must involve fundamental changes in the social relationships among teachers and students" (p. 298, emphasis added).

The typical school literacy practices place an extremely high premium on parents engaging their children in book-related experiences in a deliberate and planned manner. The traditional viewpoint is that students will benefit from typical middle-class reading related experiences. Tizard, Schofield and Hewison (1982), for example, conducted a study in a "disadvantaged working class" area of London, England where a group of parents agreed to listen to their children read aloud at home. Reading aloud to parents was associated with significantly higher scores on standard reading tests. The authors concluded, among other things, that ". . . collaboration between teachers and parents was effective for children of all initial levels of performance. ..." (p. 14). The collaboration involved parents coming to understand the methods and benefits of hearing their children read aloud. We do not criticize the researchers' efforts since we understand they were trying to learn how they could improve "disadvantaged" students' performance. We do suggest, however, that this view of collaboration implies that the school represents the correct view of literacy and literacy activities.

\section{HOME LITERACY EXPERIENCES}

Book-related experiences such as story time and book reading (Wells, 1981; Scollon \& Scollon, 1981; Varenne, Hamid-Buglione, McDermott \& Morison, 1982) are clearly not the only sources of literacy experiences. Work by such scholars as Heath (1980) informs us that children who have had extensive book experiences in their pre-school years arrive at school with the type of orientation to literacy and literacy activities that teachers prefer. Not only are children with extensive book-related experiences well versed with knowledge about print and its conventions, they have also been socialized into (a) middle class, majority language patterns of storytelling, and (b) classic classroom interaction patterns (e.g., solicit-response-evaluation) upon which schools are institutionally prepared to capitalize. Indeed, learning in the early years is so predisposed to this type of "readiness" that lack of pre-school experiences with books is considered to be one predominant source of poor school performance in lower-class and minority language students. In Becoming a Nation of Readers (Anderson, Hiebert, Scott \& Wilkinson, 1985), the U.S. National Academy of Education stated that "The single most important activity for building the knowledge required for eventual success in reading is reading aloud to children" (p. 23). 
However, as we know from work such as that done by Heath $(1980,1982)$, Anderson and Stokes (1982), Teale (1986); and Moll and Diaz (1987), working-class and ESL students do engage in a wide variety of literacy activities and parents in working-class and ESL homes do try to ensure that their children come into contact with and learn about print, practices that may differ, however, in style and focus from those assumed as standard by the school. Heath's (1983) detailed report of literacy practices in three communities found literacy orientations different from the kind required in school, differences which divided along ethnic and class lines. This work, together with other research (Schieffelin, 1982 with Southeast Asian immigrants in Philadelphia; Scribner and Cole, 1981 with the Vai in Liberia), indicates that the social definition of literacy may vary as a result of the nature of the social and cultural context of literacy in the community and in the home. The correlation between the lack of book-related experiences and poor school performance may relate not so much to whether or not children are read to but to the gap between school and home conceptions of literacy and literacy activities. Edelsky (1991) poses the essential question: "Just how do the social relations of literacy events and the features of the reading process impinge on each other?" (p. 94).

\section{MAKING CONNECTIONS BETWEEN TEACHING \& THE CHILD}

While there have been many studies describing existing conditions and practices of literacy within home/community, only a few have implemented instructional changes. In addition, only a few have attempted to relate home and school literacy views and practices. The Kamehameha Early Education Project (KEEP) in Hawaii, Heath's work in the Appalachians and work in San Diego are probably the best known and most influential related to ESL and minority language students.

In Hawaii, teachers shifted the focus of instruction in reading from decoding to comprehension and incorporated a native Hawaiian speech event, the "talk story" into their reading lessons to accommodate cultural elements of literacy practice. In addition, with the help of native Hawaiian teachers, discussion in KEEP classrooms was changed, (a) to include interaction patterns which were more comfortable for the children, and (b) to build into the discussion opportunities for the children to relate the learning to their personal experiences. Thus, the talk story lessons differed from the previous traditional lessons not only in the content and genre of the subject matter but also in that they permitted, along with traditional teacher nomination patterns, mutual or joint participatory responses from students. These patterns 
of discussion once again accommodated classroom instruction to cultural elements of the native Hawaiian writer. These accommodations proved successful as measured by gains in student performance (Au, 1980; Tharp, 1982; Tharp \& Gallimore, 1988).

Heath (1983) worked co-operatively with parents and teachers on a series of writing projects to make them similar to those they were involved in at home. Among the changes made in the various projects the teachers adapted their questioning style to that used by the students' parents in non-school settings. For example, teachers began their lessons by asking questions such as "What's happening here?" or "What's this like?". These questions were not only more familiar than those used in the school setting, they were also intended to elicit responses which tapped the students' personal experiences or enabled them to draw from similar experiences. After teachers had increased student participation through the use of home-style questions, they introduced them to and began using school-type questions. In addition, the teachers became researchers collecting data on talk and questioning styles in their own families and in the classroom. This process "led them (the teachers) to ask questions of their own practices and admit other practices which would not necessarily have emerged otherwise" (Heath, 1982, p. 127). The students, too, were encouraged to become researchers. A group of fifth grade students, who were experiencing academic difficulties, learned about growing foodstuffs by reading back-issues of the local newspaper, interviewing people who lived in the local community and collecting life histories, a process which Heath (1983) claims helped students to move "between the personalized, contextualized, orally-expressed knowledge of home to the depersonalized, decontextualized, primarily written knowledge of the classroom" (p. 238). In a grade two class in Appalachia, students explored the ways in which language changed across social contexts. As well, they kept logs of the literacy events in which they engaged in their home/community and brought in written samples. As with KEEP, activities such as these designed to link the home-school contexts proved successful, as evidenced by gains in student performance.

Moll and Diaz (1987) summarized classroom research undertaken as part of a larger literacy study conducted among Hispanic ESL students in San Diego. The researchers gathered ethnographic data to profile writing occurring in the home/community and then developed and implemented a series of writing modules that integrated features of community activities. Unlike KEEP and Heath's work, these researchers did not find any literacy events, such as "talk story" or particular questioning styles, specific to "Chicanos". However, as in 
the other two projects they did observe teachers assuming the role of full-fledged research collaborators, a key activity in the link between community and classroom practice. In this role teachers learned that it was essential to design lessons that reflected the social issues they had identified. However, establishing community concerns as the topic/content of literacy events is not enough; as in Heath's work, the students in San Diego were encouraged and supported in collecting information from their elders on specific topics. These homework assignments increased both the teacher's and the students' knowledge about a topic and thus demonstrated the value of extracurricular resources. Homework wasn't the object of the research, but rather it was a way to explore the community to discover ways to improve writing and to survey instructional resources. They note, "Instructional change may occur in several ways. In our experience, it started by making the researchers, and through the researchers, the teachers, aware of the importance of explicitly shaping instruction through the social issues identified by the ethnographic interviews and observations" (p. 217).

These projects share some important features. The students contextualized reading and writing in their home/community and school life. They looked upon literacy in school as something attached and vital to information needed and work done in the larger world. In addition, students played an active role and exercised some control of their own reading, writing and learning.

\section{INSTRUCTIONAL SUGGESTIONS}

It is important to note, as Schickendanz and Sullivan (1984) have, that homes are not schools. Indeed, the difference may account for some of the difficulties certain students have since ". . students seem to grow increasingly disenchanted with the activities they are learning to master" (Langer, 1984, p. 111, emphasis added). Any instructional suggestions must take into account the nature of the classroom and its own particular socio-cultural context including, as it does, one adult and a great many children. Bearing this in mind, drawing on studies that have systematically considered literacy environments, as well as data from classroom observations in Vancouver, British Columbia, this section of the paper contains a discussion of approaches linking home and school literacy.

\section{VIEWING THECLASSROOM AND SCHOOLAS COMMUNITIES}

One way to approach the link is to conceive of the classroom itself as a community, one with its own practices, principles and values. As exemplified in the introduction, there are opportunities for many 
authentic activities for purposeful writing within the classroom community. Indeed, we suggest that an early ethnographic study of the classroom be conducted by both students and the teacher, a study that would provide interesting data about the literacy uses and demands of a particular classroom. Some examples, from observations and from literature, of types of classroom activity to foster a classroom community follow:

- Student-run postal systems promote interaction with class members and between the class as a whole and the entire school or larger community;

- Dialogue-journals promote a wide range of writing types including joking, expressing feelings and personal opinions, reflecting and interacting (e.g., explaining, inquiring, comforting, confiding, complaining, complimenting, giving advice) in a variety of ways with their teacher (Milz, 1980; Staton, 1980; Wells-Lindfors, 1988);

- Plans, lists, notes, signs, instructions, labels, advertisements, letters and book reviews enrich learning across content areas (Edelsky \& Smith, 1984);

- Students can share their thoughts, observations and experiences with others by reading or publishing their own personal narratives, poems and expository prose (Graves, 1983);

- Creating class newspapers/newsletters around special themes or events or on an ongoing basic, including editorials, puzzles, jokes, letters to the editor, sports and local news, also foster students' understanding of the processes and functions of written language in a community;

- Billboards, bulletins, comic strips, contracts, game rules, graffiti, menus, posters, quizzes, recipes, riddles, schedules, tributes and want ads serve legitimate personal and social purposes for writing in the classroom;

- Interviewing students and staff in the school community on topics related to class themes;

- establishing cross-age and peer tutoring programs; and

- promoting school-wide topical projects (e.g., "Caretakers of the Earth") are but three common ways that are suggested in the literature and frequently observed in practice.

Clearly, these literacy activities in the classroom and school community parallel literacy events in the broader community. These types of literacy events not only help students to learn to write, but also importantly, they convey a message to students that writing is a personally useful activity, a tool to get things done both in school and 
in the "real world". How students come to view literacy (i.e., the social and affective value that they place upon literacy) is as important as the act of lcarning to read and write. The two are not easily separated.

\section{REACHING OUT TO THE COMMUNITY}

A second approach to linking home and school literacy is to design classroom instructional practices which reach out to the broader community. These may include:

- studying the local community,

- interviewing residents,

- writing histories,

- drawing maps,

- searching local archives,

- making slide presentations,

- collecting photographs and the like,

- taking field trips to local places of interest, and

- involving community members, including parents, in classroom activities as guest speakers, helpers or guests at special events.

While on the surface classrooms which reach out to the community may appear innovative and enabling, like everything else in education this can be done well or it can fail to achieve its real potential for learning. On the negative side, activities designed to reach out to the broader community can be as contrived and unauthentic as the most traditional of instructional practices. In these contexts, the teacher must be an informed-knower, firmly and traditionally in control of the learning, determining the rightness and 'neatness' of the students' products which more than likely end up selectively 'packaged' on bulletin boards. Conversely, when teachers and students become ethnographers genuinely working together to research and critically examine a real social issue considered important by community members the task becomes authentic. Importantly, the potential for enhancing understanding between school faculties and community members is increased and a context is created in which to link home/community literacy practices.

\section{Some Gencral Concerns}

In multilingual, multicultural classrooms and communities, it is likely, as in the Moll and Diaz (1987) study, that the social issues of concern will be language/culture related. In this instance it provides an excellent opportunity to make language itself, not grammar, the focus of consideration. Examples of this type of approach to learning can be found in what have come to be known in Britain as "language 
awareness programs" (Wallace \& Goodman, 1989). In addition, Edelsky (1989) describes and outlines some of the key features of ethnographic approaches to making "communities' knowledge the curricular focus" (p. 104). In programs such as these the social issues of community concern (e.g., attitudes to bilingualism, uses of literacy, power relationships between groups in society or responses to literature) are identified. This can be accomplished through interviews and observations or from a consideration of recurring themes at parent meetings, community or religious meetings, or parent or teacher interviews. The project work can be divided among individuals or groups.

In this scheme of things, ethnography is not merely "played at". Teachers and students endeavour to develop definite ethnographic skills and techniques. They learn how to plan interview questions, to get written permission from informants, take notes, develop taxonomies and folk definitions, draw up time and action plans, develop decision-making skills and decision models. They learn how to keep logs, organize and display data, interpret causal relations and multiple perspectives and draw up interim explanations and interpretations. Moreover, in this work the teacher is not directly "in control" of the knowledge gained. Teacher and student together must grapple with sorting and interpreting the data and developing ways to display their ongoing realizations.

\section{Ethnography in Action}

Jane teaches grade four in an inner-city school located near Vancouver's "Chinatown" in which eighty-five percent of the student body is from families whose home-language is either Cantonese or Mandarin, about forty-five percent are immigrants. Jane's classroom is complex. She teaches monolingual English-speaking Chinese Canadians, bilingual Cantonese-English and Mandarin-English speaking Chinese Canadians, monolingual Cantonese- and Madarinspeaking immigrants, and ESL students of various proficiency levels who are Canadians and immigrants. All of the immigrants she teaches are literate in Chinese; she found this out as part of her own ethnographic study, and most have studied English to some extent before they immigrated to Canada. There is also one Portuguese-CantoneseEnglish trilingual student. One of the first activities Jane introduces early each September is a class reading/writing survey conducted by students, first in the classroom, followed by studies of the school, the neighborhood, and finally the home.

Students follow a basic outline of questions to discover the kinds of reading/writing activities different individuals are involved in and 
their reasons for doing them. Students observed and made notes of literacy events in their homes and in their neigborhoods. They were trained to ask about the purposes of reading and writing activites. Teacher-led classroom discussions focused on the different uses of literacy in different contexts. A class project produced a book titled "We All Read and Write," in which different literacy activities involving the teacher, the students, other students, the parents, and community people were reported, including comments from studentauthors about purposes. There was a great deal of information that informed Jane's learning program. She discovered, for example, such items as: most of her students studied Chinese after school; many parents regularly read L1 books to their children at home; many parents struggled to read and write "survival" material in English; students often helped their parents in English literacy; fathers were more likely to study English formally; most families subscribed to Chinese newspapers and magazines; most families had L1 children's books; many families also had collections of children's books written in English; older brothers and sisters appeared to prefer to read materials written in English, the most often observed materials written in English not including school books, were the Sports Page, teenage fashion magazines, car magazines and the Drivers Licence Manual; a few families had FAX machines they used to send letters written in Chinese to friends and relatives; parents often asked their children to translate orally or into writing for them; homework was expected and time was set aside by most parents for children to attend to it; mothers and grandmothers were most often the adults who did not learn to read and write English; an adult's level of scholarly achievement could be judged by his or her calligraphy, and; everyone observed read and most wrote something in either English or Chinese. They found no one who did not read or write, except babies. They compiled a list of purposes for writing that had one hundred forty-three items.

Jane's class and school community is unique. As a result of the survey she invited parents in to her classroom to read books written in Chinese to her students. Monolingual Chinese parents can make valuable school contributions to the school's language program (see Walters \& Gunderson, 1985). In addition, she contacted the local Community College and purchased guides to survival literacy skills for parents. For instance, one extremely useful pamphlet written in Chinese described and showed parents how to write in English "absence notes" explaining their childrens' absences from school. Jane's language arts program was informed by her students' study of literacy.

Not so far from Jane's school is another Vancouver school that 
houses about three-hundred and fifty students, about eighty-five percent were from Indo-Canadian and immigrant East Asian families. A student-conducted literacy ethnography revealed interestingly different patterns in reading and writing behaviors. It too informed the teacher's language arts program. Ethnography reveals to teachers and to students that school activities represent a small proportion of the literacy uses in the community. It also reveals that reading and writing have real and important purposes at home, in the community, and at school.

\section{The Long-Term Value of Ethnography}

Some of the positive aspects of this approach in promoting better understanding are that work has value in society; the skills the students learn will serve them not only in different school contexts but in life and later in work. The teacher is actively involved in learning; this affords the teacher an opportunity to model learning, including intentional learning for students. Further, in these types of settings the audiences are 1) real, 2) the purposes of writing authentic (to communicate, as a tool of analysis for intellectual development, for reflection and pleasure) and 3) the student is in some considerable. measure in control of his or her learning.

\section{Validating Home Literacy in the School}

Some teachers working in this fashion may be threatened. There are no right answers or textbooks, no tangible end products, few models or cvaluative norms to follow. As teachers/ethnographers we can bridge the distance between ourselves and our students and between students' home and school values for literacy. In the process we can validate the students' perspectives and come to understand them better. Thus we provide not only a way to link the organization of instruction to the social world of the child but a way to promote respect among children, and between home and school community members. Without teacher initiation to bridge the gap, the child is left to do this on his or her own. There is more to focus on than simply the traditional home oral reading program, the learning of skills to enable students to succeed at school. It is important for students to learn the literacy skills that will allow them to survive in school and in society; home reading programs may be valuable in this respect. However, a broader perspective of literacy and literacy uses must be taken. Cummins (1986, reprinted 1991) believes that ". . . students from dominated socictal groups are empowered or disabled as a direct result of their interactions with educators in the schools" (p. 375, emphasis added), while Smith (1987) states that "In fact, so strong is 
the school's vested interest in controlling the acquisition of literacy skills that much of the naturally acquired skill in encoding and decoding that children bring with them to school is systematically overlooked" (p. 59, emphasis added). Literacy uses, attitudes, and contexts vary from culture to culture, from community to community, and from home to home. A useful alternative is to learn about differences, to value them as being as valid as the predominant standard school views, and to design instructional programs that incorporate them.

\section{THE AUTHORS}

Margaret Early and Lee Gunderson are Associate Professors in Language Education at the University of British Columbia. Margaret's research focuses on the integration of language and content and program planning for school-aged ESL students, while Lee is currently exploring the predictors of L2 literacy achievement for recent immigrants.

\section{REFERENCES}

Anderson, R. C., Hiebert, E. H., Scott, J. A. \& Wilkinson, I. A. G. (1985). Becoming a nation of readers: The report of the Commission on Reading. Washington, DC: The National Institute of Education, U.S. Department of Education.

Anderson, A. B., \& Stokes, S. J. (1982). Social and institutional influences on the development and practice of literacy. In H. Goelman, A. Oberg, \& F. Snith (Eds.), Awakening to literacy (pp. 24-37). Exeter, NH: Heinemann Educational.

Au, K. H. (1980). Participation structures in reading lessons with Hawaiian children: Analysis of a culturally appropriate instructional event. Anthropology and Education Quarterly, 11(2), 91-115.

Cummins, J. (1991). Empowering minority students: A framework for intervention. In M. Minami \& B.P. Kennedy (Eds.) Language issues in literacy and bilingual/multicultural education. Cambridge, MA: Harvard Educational Review, Reprint Series No. 22, pp. 372-390 (original publication, Han ard Educational Review, 1986, 56(1), 18-36.

Edelsky, C. (1989) Putting language variation to work for you. In P. Rigg and V.G. Allen (Eds.) When tho don t all speak English (pp. 96-107). Urbana IL: National Council of Teachers of English.

Edelsky, C. (1991). With literacy and justice for all: Rethinking the social language and education. Bristol, PA: The Falmer Press, Taylor and Francis.

Edelsky, C. \& Smith, K. (1984). Is that writing-or are those marks just a figment of your curriculum? Language Arts, 61, 24-32.

Graves, D. H. (1983). Writing: Teachers and children at work. Exeter, NH: Heinemann.

Heath, S. B. (1980). The functions and uses of literacy. Joumal of Communication, 30(1), 23-56.

Heath, S. B. (1982). What no bed time story means: Narrative skills at home and school. Language in society 11, 49-76.

Heath, S. B. (1983). Ways with words: Language, life and work in communities and classrooms. Cambridge: Cambridge University Press. 
Langer, J. A. (1984). Literacy instruction in American schools: Problems and perspectives. American Joumal of Education, 93, 107-132.

Milz, V. (1980). First graders can write: Focus on communication. Theory into practice, 19, 179-185.

Moll, L., \& Diaz, R. (1987). Teaching writing as communication: The use of ethnographic findings in classroom practice. In D. Bloome (Ed.), Literacy and schooling (pp. 195-221). Norwood, NJ: Ablex.

Moll, L., \& Diaz, R. (1987). Change as the goal of educational research. Anthropology and Educational Quarterly, 18, 300-311.

Myers, J. (1992). The social contexts of school and personal literacy. Reading Research Quarterly, 27(4), 296-333.

Schickendanz, J. A. \& Sullivan, M. (1984). Mom, What does U-F-F spell? Language Aits, 61, 7-17.

Schieffelin, B. B. (1982). Talking like birds: Sound play in a cultural perspective. In J. Loy (Eds.) The paradoxes of play. West Point, NY: Leisure Press.

Scollon, R. \& Scollon, S. (1981). Narrative, literacy and face in interethnic communication. Norwood. NJ: Ablex.

Scribner, S. \& Cole, M. (1981). The psychology of literacy. Cambridge, MA: Harvard University Press.

Smith, D. M. (1987). Illiteracy as social fault: Some principles of research and some results. In D. Bloome (Ed.), Litcracy and schooling (pp. 55-64). Norwood, NJ: Ablex.

Staton, J. (1980). Writing and counseling: Using a dialogue journal. Langzıage Arts, 57, 414-518.

Stein, N. I. (Ed.). (1986). Literacy in American schools. Chicago, Ill: The University of Chicago Press.

Teale, W. (1986). Home background and young children's literacy development. In W. Teale and E. Sulzby (Eds.), Emergent literacy: Writing and reading (pp. 173-206). Norwood, NJ: Ablex.

Tharp, R. G. (1982). The effective instruction of comprehension: Results and descriptions of the Kamehameha Early Education Program. Reading Research Quarterly, 17(4), 503-527.

Tharp, R. G. \& Gallimore, R. (1988). Rousing minds to life: Teaching leaming and schooling in social context. New York: Cambridge University Press.

Tizard, J., Schofield, W. N. \& Hewison, J. (1982). Collaboration between teachers and parents in assisting children's reading. British Journal of Educational Psychology, 52, 1-15.

Varenne, H., Hamid-Buglione, V., McDermott, R. \& Morison, A. (1982). I teach him everything he leams in school: The acquisition of literacy for learning in working class families. New York: Columbia Teachers College, Elbenwood Center for the Study of the Family as Educator, NIE.

Wallace, C. \& Goodman, Y. (1989). Language and literacy development of multilingual learners (Research Currents). Language Arts, 66(5), 542-551.

Walters. K. \& Gunderson, L. (1985). Effects of parent volunteers reading first language (L1) books to ESL students. The Reading Teacher, 39(1), 66-69.

Wells, G. (1981). Preschool literacy-related activities and success in school. Paper presented at the Cognitive Consequences of Literacy Conference. Ontario Institute for Studies in Education. Toronto.

Wells-Lindfors, J. (1988). From "Talking Together" to "Being Together in Talk. Language Arts, 65(2), 135-141. 